\section{Mayhaws: Trees of Pomological and Ornamental Interest}

Since antebellum times, mayhaw [Cataegus aestivalis (Walter) Torrey \& Gray, C. opaca Hook. \& Arn., C. rufula Sarg.] fruit has been treasured for culinary uses in the U.S. deep South (Elliott, 1971). Mayhaws merit attention not only for their delightful aromatic fruit, but also because they are one of the few ornamental flowering trees adapted for use in lakeshore and wet-area landscaping. Mayhaws are members of the family Rosaceae, subfamily Maloideae, tribe Crataegeae. This round-topped, small tree (8 to $10 \mathrm{~m}$ high) has outstanding ornamental characteristics: attractive foliage, showy white to pale pink blossoms (15 to $28 \mathrm{~mm}$ in diameter), clusters of brilliantly colored fruits, and an upright or pendulous tree form. Mayhaws are locally abundant in low, wet areas in limesinks, bays, sloughs, river bottoms, and along streams and in swamps from North Carolina to Florida and west to Arkansas and Texas (Fig. 1) (Clewell, 1985; Coker and Totten, 1945; Correll and Correll, 1975; Correll and Johnston, 1970; Godfrey and Wooten, 1981; Kurz and Godfrey, 1962; Mohr, 1969; Phipps, 1988; Radford et al., 1974; Sargent, 1965; Small, 1913; West and Arnold, 1952). Hawthorns are easily recognized as a group (genus), but species are extremely difficult to distinguish due to polyploidy and apomixis (Cronquist, 1981; Phipps, 1983). More than 1100 species have been described from North America (Bailey, 1960; Rehder, 1960), but only those early ripening, palatable,

Received for publication 25 Sept. 1989. We thank Sherwood Akin. Jerry Baron. Major Collins, Tom Cracker, Herbert Durand, Joseph Elson, Harvey Gaskamp, Joe Hennen, Wayne McLaurin, Charles Mims, Jane and Maurice Palmer, Burl Turnage, and T. 0 . Warren for freely sharing their knowledge, experience, and unpublished data on mayhaw products, culture, plantings, propagation, and processing. We gratefully acknowledge the following for input in native mayhaw distribution: Alabama, John D. Freeman; Arkansas, Edwin B. Smith; Florida, Loran C. Anderson and Robert K. Godfrey: Georgia, Nancy Coile and Laurie Consaul; Louisiana, R. Dale Thomas and Lowell E. Urbatsch; Mississippi, Sidney McDaniel; North Carolina, J.R. Massey; South Carolina, Cynthia Aulbach-Smith and Victoria Hollowell; Texas, Herbert Durand and Elray Nixon. We are especially indebted to J.B. Phipps, Ontario, Canada, for sharing his unpublished distribution of mayhaw. The cost of publishing this paper was defrayed in part by the payment of page charges. Under postal regulations, this paper therefore must be hereby marked advertisement solely to indicate this fact. haws. Rogers, 1988).
Crataegus spp. (series Aestivules) from the southern United States are considered may-

Mayhaw trees flower profusely and early (late February to mid-March in southern Georgia, USDA zone 9A) on previous season's shoots and spurs. Fruit ripens mostly in early May; hence, the name mayhaw. Mayhaw fruit is a small pome ( 8 to $19 \mathrm{~mm}$ in diameter), yellow to bright red, fragrant, acid, and juicy, resembling cranberries in appearance with a crabapple-like taste. Studies conducted on mayhaw fruit from the 1989 season showed the fruit to be rich in K (152$245 \mathrm{mg} / 100 \mathrm{~g}), \mathrm{Ca}(20-56 \mathrm{mg} / 100 \mathrm{~g})$, ascorbic acid (23-40 mg/100 g) and high in $\beta$ carotene $(226-1200 \mu \mathrm{g} / 100 \mathrm{~g})$. These values compare favorably with those from the Mexican hawthorn (C. mexican Moc. \& Sesse) and the Chinese hawthorn $(C$. pinnatifida Bunge) (Coetzee et al., 1950; Rogers and

Until recently, the fruit has only been used locally in marmalades, butters, preserves, jellies, condiments, syrups, wines, desserts, and as food for wildlife (Elliot, 1971; Gibbons, 1974; Halls, 1977; Hedrick, 1919; Morton, 1963; Reynolds and Ybarra, 1984; Wood, 1864). However, during the past 5 to 10 years, mayhaws have received attention as a source of income for cottage industries. The fruit, netted from the water or hand-harvested from native trees, wholesales for $\$ 2.75$ to $\$ 4.40 / \mathrm{kg}$ ( $\$ 5$ to $\$ 8 /$ gallon) and jelly retails for up to $\$ 18.00 /$ liter ( $\$ 8.50 /$ pint). There are, at present, at least eight commercial manufacturers of the jelly in the southeastern U.S. Because demand exceeds supply, many farmers and entrepreneurs, and some re-

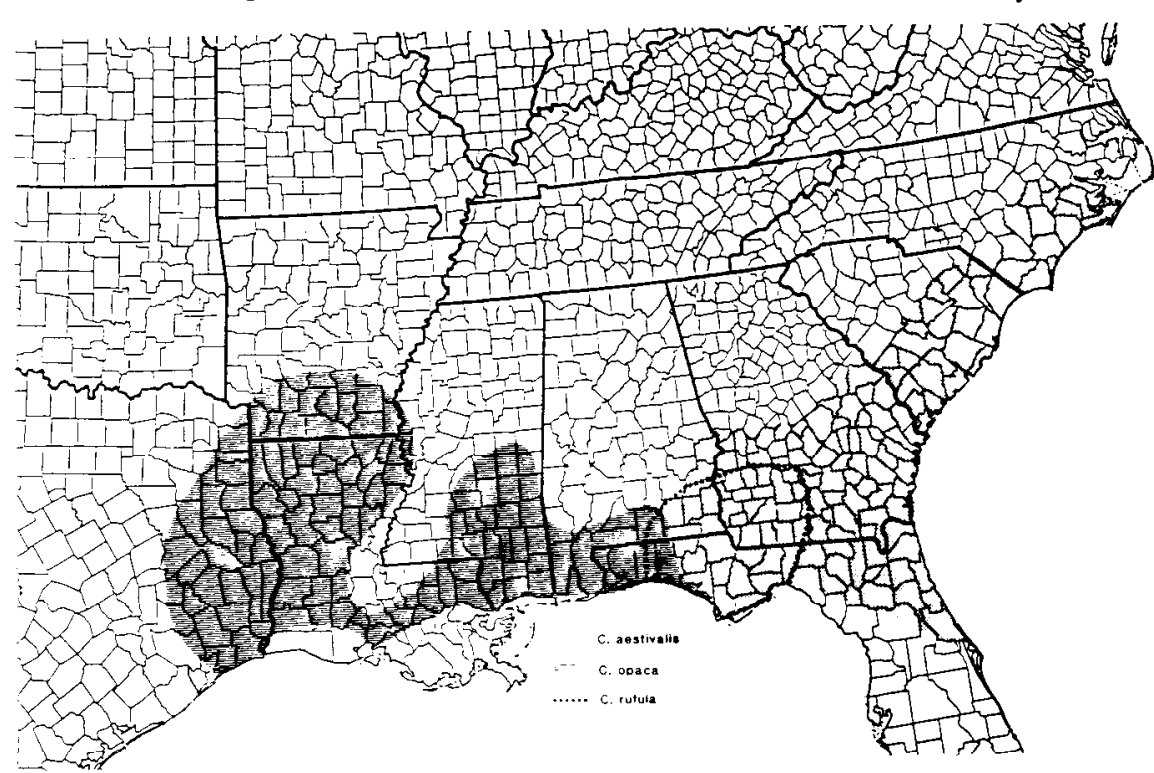

Fig. 1. Native range of mayhaw (Crataegus aestivalis, C. opaca, C. rufula) in North America

Fig. 1. Native range of mayhaw (Crataegus aestivalis, C. opaca, C. rufula) in North America.
(continued on inside back cover) searchers, are showing interest in culture and use of this native plant.

\section{HORTICULTURE}

Propagation. Under natural conditions, hawthorn seeds do not germinate until overwintered (Hartmann and Kester, 1983). Crataegus species have embryo dormancy and require treatment in a moist medium at low temperature before germination will occur (Schopmeyer, 1974). Seeds are an easy way to produce plants, since nucellar seedlings, which produce fruit like the mother tree, are common in mayhaws (W.B. Sherman, personal communication).

Mayhaw cuttings can also be rooted under during the summer (Payne and Krewer, 1990). Propagation from hardwood and root cuttings has also been reported by nursery workers; however, no details were revealed. Mayhaws are easily grafted during dormancy (late winter). A whip-and-tongue or simple whip graft can be used. Cleft grafting can be used on larger trees.

Rootstock. Mayhaw appears to be initially compatible with any hawthorn species. In Mississippi, the parsley haw (C. marshallii Egg].) is considered an excellent rootstock for C. opaca (McDaniel, 1980). Good results have been reported using cockspur (C. crus-galli L.) and Washington hawthorn [C. phaenopyrum (L.f.) Med.] rootstock in Texas for $C$. opaca. Trials with $C$. opaca in Louisiana, however, have produced variable results with Washington hawthorn. C. aestivalis can also be grafted onto commercially available Washington hawthorn seedlings, but it is not known how they will perform at maturity. In Georgia, the hoghaw (C. flava Aiton), which grows on sand ridges, can be used, but, due to its slow growth rate, the mayhaw scions may overgrow the hoghaw rootstock. Mayhaw seedlings are probably the best choice as a rootstock in damp soils.

Cultivars. About a dozen mayhaw selecintermittent mist or in a humidity chamber 
(continued from inside front cover) tions have been collected from the wilds (river bottoms, lime-sink, swamps, sloughs) of Georgia, Mississippi, Louisiana, and Texas, with attention given to size of fruit, harvest or ripening period and yield (Payne and Krewer, 1990); however, information from field trials is very limited. Most ripen over a 30-day harvest period, but 'Lori' (C. aestivalis) may have $80 \%$ of the fruit ripe at one time. 'Super Spur' (C. opaca) appears to be one of the best from the standpoint of yield and tree form. Yields of $30 \mathrm{~kg} / \mathrm{tree}$ have been reported for 30- to 40-year-old wild mayhaws in Georgia and $60 \mathrm{~kg}$ for a 15year-old 'Super Spur' in Louisiana. Preliminary reports indicate that current mayhaw cultivars are best-adapted to USDA zones 9A and 9B. Although most cultivars have a low chilling requirement ( 250 to $500 \mathrm{hr}$ at $\leq 7 \mathrm{C})$ and bloom early, some unnamed selections under test should be adapted to the piedmont of the southeastern U.S. Most $C$. aestivalis cultivars bloom a few days later than $C$. opaca cultivars, and may be better choices further north. Bloom occurs over an extended period of time and the fruit are reported to be fairly frost hardy once past the bloom period. Tree winter hardiness is good, but data on flower bud winter hardiness are limited. There have been reports of mayhaws fruiting after $-25 \mathrm{C}$ and 2-year-old trees survived $-32 \mathrm{C}$ without damage; however, fruit production has been poor under these conditions (Akin, 1985).

Orchards. Although tolerant of wet, very acid soils ( $\mathrm{pH}<5.0$ ), better growth has been observed when mayhaws are planted on welldrained, slightly acid soils ( $\mathrm{pH}$ 6-6.5). Mayhaw trees are long-lived and may have a 9$\mathrm{m}$ canopy diameter after 20 years. A spacing of $\approx 6.1 \times 6.1 \mathrm{~m}$ is suggested to provide sufficient space for mechanical or hand harvesting. Yearly pruning to remove low branches and to open up the tree canopy for greater light penetration may be necessary with most cultivars.

Pest problems. There is limited information on the pest management of mayhaws; however, it is known that they are susceptible to many of the insects and diseases that attack other pome fruits (Crops Res. Div., 1960; Forest Service, 1985). Several insects, including plum curculio [Conotrachelus nenuphar (Herbst)], apple maggot [Rhagoletis pomonella (Walsh)], hawthorn lace bug [Colythuca cydoniae (Fitch)], flower thrips (Frankliniella spp.), roundheaded appletree borer (Saperda candida F.), flatheaded appletree borer [Chlysobothris femorata (Olivier)], whitefringed beetle (Graphognuthus spp.), apple blotch leafminer (Phyllonorycter crataegella (Clemens)], terrapin scale [Mesolecanium nigrofasciatum (Pergande)], cottony maple scale [Pulvinaria innumerabilis (Rathvon)], apple mealybug [Phenacoccus aceris (Signoret)], and pear sawfly [Caliroa cerasi (L.)] feed on the foliage, flower, fruit, and wood of mayhaw. The plum curculio and apple maggot, in particular, have caused extensive damage to fruit in some locations and will probably require preventive treatment.
There are numerous diseases known to occur on various hawthorn species, but little information is available on diseases of mayhaws. Quince rust (Gymnosporangium clavipes Cke. \& Pk.) and American hawthorn rust (G. globosum Farl.) have been severe on some mayhaws native to southern Georgia and northern Florida and several $C$. aestivalis and C. opaca cultivars since 1983. At present, no rust control recommendations are available except the planting of rust-free selections. At this time, only two pesticides, insecticidal soap and rotenone/pyrethrin, can be used for pest control on mayhaws destined for food use.

\section{PROSPECTS}

Although mayhaw appears to be initially compatible on most Cratacegus rootstocks, our knowledge of mayhaw rootstocks is rudimentary at best. There is little published information available on the productivity and long-term compatibility, because mayhaw orchard plantings have existed $<5$ years. Existing information on methods of propagation is also very limited. Cultivar evaluations have not been conducted in replicated orchard plantings, and low-chilling requirements of many cultivars may limit their commercial adaptability to zone $9 \mathrm{~A}$ or $9 \mathrm{~B}$.

Research possibilities are unlimited. Preliminary research projects are underway by university personnel in Georgia, Mississippi, Louisiana, and Texas, especially with regard to cultivar evaluation and pest control. If the industry is to greatly expand, cultivars adapted to mechanical harvesting are desired. There are many potential products made from mayhaws, such as juices, jellies, preserves, candies, pastries, and wine. At this point, only the jelly manufacturing has been investigated by university or industry personnel. Thus, the potential exists for a greatly expanded market dependent upon a consistent supply of fruit. Unless problems associated with production are solved, the traditional harvest from native stands will be insufficient to allow for alternate product development.

\section{Literature Cited}

Akin, J.S. 1985. Mayhaw coming out of the swamp. Pomona 18(1):70-73.

Bailey, L.H. 1960. The standard cyclopedia of horticulture. Macmillan, New York.

Clewell, A.F. 1985. Guide to the vascular plants of the Florida panhandle. Florida State Univ. Press, Tallahassee.

Coetzcee, W.H.K., J.F. du T. Hugo, and F.F. Pratt. 1950. The Mexican hawthorn: An investigation of its possibilities for the processing industry. Farming in South Africa. Nov. p. 361-362.

Coker, W.C. and H.R. Totten. 1945. Trees of the southeastern states. Univ. of North Carolina Press, Chapel Hill.

Correll, D.S. and H.B. Correll. 1975. Aquatic and wetland plants of southwestern United States. vol. 2. Stanford Univ. Press, Stanford, Calif.

Corrcll, D.S. and M.C. Johnston. 1970. Manual of the vascular flora of Texas. Gcorge Banta Co., Menasha, Minn.

Cronquist, A. 1981. An integrated system of classification of flowering plants. Columbia Univ. Press, New York.

Crops Research Division-USDA. 1960. Index of plant diseases in the United States. U.S. Gov- ernment Printing Office, Washington, D.C. Agr. Hdhk. 165

Elliott, S. 1971. A sketch of the botany of South Carolina and Georgia. vol. 1. Hafner, New York. (Reprint of 1821 edition.)

Forest Service-USDA. 1985. Insects of castern forests. U.S. Government Printing Office, Washington, D.C. Misc. Publ. 1426.

Gibbons, E. 1974. Stalking the healthful herbs. David McKay Co.. New York.

Godfrey, R.K. and J.W. Wooten. 1981. Aquatic and wetland plants of southeastern United States: Dicotyledons. Univ. of Georgia Press, Athens.

Halls, L.K. 1977. Southern fruit-producing woody plants used by wildlife. USDA Forest Service, New Orleans, La.

Hartmann, H.T. and D.E. Kestcr. 1953. Plant propagation principles and practices. PrenticcHall, Englewood Cliffs, N.J.

Hedrick, U.P. 1919. Sturtevant'a notes on edible plants. J.B. Lyon, Albany, N.Y.

Kurz, H. and R.K. Godfrey. 1962. Trees of northern Florida. Univ. of Florida Press, Gainesvillc.

McDaniel, J.C. 1980. More on hawthorn as a rootstock. Pomona 13(3):169-170.

Mohr, C. 1969. Plant life of Alabama. vol. 2. J. Cramer, New York.

Morton, J.F. 1963. Principal wild food plants of the United States excluding Alaska and Hawaii. J. Econ. Bot. 17:319-330

Payne, J.A. and G.W Krewer. 1990. Mayhaw: A new fruit crop for the south. In: J. Janick and J.E. Simon (eds.). Advances in new crops. Proc. First Natl. Symp., New Crops: Research, Development, Economics. Timber Press, Portland, Ore. (In press.)

Phipps, J.B. 1983. Biogeographic, taxonomic, and cladistic relationships between cast Asiatic and North American Crataegus. Ann. Missouri Bot. Gard. 70:667-700.

Phipps, J.B. 1988. Crataegus (Maloidcac, Rosaceac) of the Southeastern United States: I. Introduction and series Aestivales. J. Arnold Arboretum 69:401-331

Radford, A.E., H.E. Ahles, and C.R. Bell. 1974 Manual of the vascular flora of the Carolinas. Univ. of North Carolina Press, Chapel Hill.

Rchder, A. 1960. Manual of cultivated trees and shrubs hardy in North America. Macmillan, New York.

Reynolds, S. and P.W. Ybarra. 1984. So easy to preserve. Georgia Extension Service, Univ. of Georgia, Athens.

Rogers, B. and B. Powers-Rogers. 1988. Culinary botany: The essential handbook. PRP-Powers, Rogers and Plants, Kent, Wash.

Sargent, C.S. 1965. Manual of the trees of North America. vol. 2. Dover Publ. New York

Schopmeyer, C.S. 1974. Seeds of woody plants in the United States. U.S. Government Printing Office, Washington, D.C. Agr. Hdbk. 450.

Small, J.K. 1913. Flora of the southeastern United States. J.K. Small, New York.

West, E. and L.E. Arnold. 19.52. The native trees of Florida. Univ. of Florida Press, Gainesville.

Wood, A. 1864. Class-book of botany. A.S. Barnes \& Burr, Chicago, Ill.

JERRY A. PAYNe

USDA, Southeastern Fruit and Tree Nut Research Laboratory, P.O. Box 87, Byron, GA 31008 Gerard W. Krewer

Extension Horticulture Dept., P.O. Box 1209, Univ. of Georgia, Tifton, GA 31793

RONALD R. FITENMILLER Food Science and Technology Dept., Univ. of Georgia, Athens, GA 30603 